\title{
Tropane Alkaloid Production in Hairy Roots of Hyoscyamus niger Transformed with Agrobacterium rhizogenes
}

\author{
Kosaku UchidA, Masanori Kuroyanagi and Akira Ueno \\ School of Pharmaceutical Sciences, University of Shizuoka, 52-1 Yada, Shizuoka-shi, 422 Japan
}

(Received September 28, 1992)

(Accepted May 25, 1993)

Hairy roots were induced by inoculation with Agrobacterium rhizogenes (strain 15834) on sterile seedlings of Hyoscyamus niger. The axenic culture of hairy roots, isolated from the seedlings, proliferated 2760 to 3750 -fold based on the initial dry weight after five weeks of culture in Gamborg B5 (B5), Murashige \& Skoog (MS) and Woody Plant (WP) liquid media. Hyoscyamine as the main tropane alkaloid was isolated in a high yield, together with scopolamine, $6 \beta$-hydroxyhyoscyamine and $7 \beta$-hydroxyhyoscyamine from the hairy roots of $H$. niger. Rapid growth of the hairy roots was observed in WP medium, but not in B5 medium. On the other hand, a relatively high content of hyoscyamine was obtained in MS medium, but low in WP medium. B5 medium showed moderate growth and hyoscyamine production. A change in the concentrations of sucrose and potassium nitrate in the B5 medium gave improved results in growth and alkaloid production. The highest content $(2.7 \%$, dry weight) of hyoscyamine was observed in MS liquid medium.

\section{Introduction}

Some solanaceous plants have been regarded as rich sources of various alkaloids, and Hyoscyamus plants such as $H$. niger, $H$. muticus, $H$. albus are important sources of tropane alkaloids such as hyoscyamine (1), scopolamine (2), 7 $\beta$-hydroxyhyoscyamine ${ }^{1)}(3)$ and $6 \beta$-hydroxyhyoscyamine (4). Hyoscyamus plants are the medicinally important herbs which produce tropane alkaloids, which 1

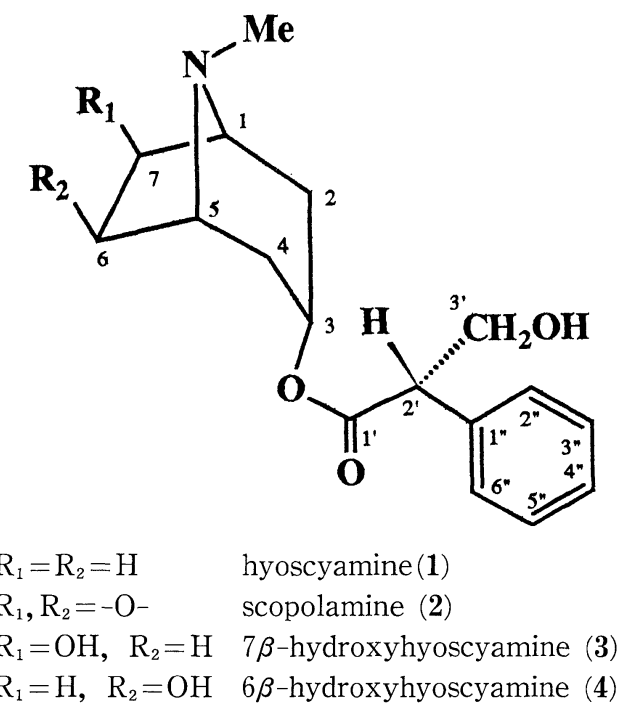


have a stimulant action on the central nervous system and $\mathbf{2}$ are a parasympatholytic agent. Production of tropane alkaloids by cultures, such as the cell suspension culture and root culture of H. niger ${ }^{2)}$, the hairy root of $H$. muticus ${ }^{3)}$ and H.albus ${ }^{4,5)}$ have been reported.

Agrobacterium rhizogenes ${ }^{6}$ (cause the formation of transformed hairy roots by introducing $\mathrm{T}$ DNA of the Ri plasmid into the genomic DNA of the host plant cells. The hairy roots have the advantages of increased growth rate without the addition of plant hormones, and an expected higher production of secondary metabolites. We induced hairy roots in $H$. niger by the inoculation of $A$. rhizogenes (strain 15834). From the hairy roots, tropane alkaloids were isolated and their structures were elucidated. The growth and tropane alkaloid productivity of the hairy roots are discussed in this report.

\section{Materials and Methods}

\section{General procedures}

${ }^{1} \mathrm{H}-\mathrm{NMR}(500 \mathrm{MHz})$ and ${ }^{13} \mathrm{C}-\mathrm{NMR}(125.6 \mathrm{MHz})$ spectra were measured on a JEOL GSX-500 FTNMR spectrometer. FAB-MS was recorded on a JEOL JMX-SX 102 mass spectrometer using $m$ nitrobenzyl alcohol as a matrix. Optical rotations were recorded on a JASCO DIP-360 Digital Polarimeter. High performance liquid chromatography (HPLC) was carried out by the ionpair method on a YMC packed column R-ODS-7 using the solvent system of a solution composed of 48 volumes $\mathrm{MeOH}$ and 52 volumes of $10 \mathrm{mM}$ sodium 1-heptanesulfonate in $\mathrm{H}_{2} \mathrm{O}$ (pH 4.0 with acetic acid ${ }^{7}$. The chromatogram was monitored by measuring the absorbance at $215 \mathrm{~nm}$.

TLC was carried out on Merck precoated Kieselgel $60 \mathrm{~F}_{254}$ and spots were visualized by spraying Dragendorff's reagent and $50 \% \mathrm{H}_{2} \mathrm{SO}_{4}$. The developing solvent system was $\mathrm{CHCl}_{3}$-acetone-MeOH$28 \% \mathrm{NH}_{4} \mathrm{OH}(75: 10: 15: 2 \mathrm{v} / \mathrm{v})$.

\section{Induction and culture of hairy roots}

The hairy roots of Hyoscyamus niger were induced by direct inoculation on sterile seedlings with Agrobacterium rhizogenes strain 15834 harboring the Ri plasmid (pRi 15834). The bacteria in the generated hairy root tips were eliminated on half-strength MS (1/2 MS) solid medium containing $500 \mathrm{mg} / l$ carbenicillin and $500 \mathrm{mg} / l$ vancomycin. The axenic hairy roots thus obtained were subcultured in hormone-free MS, B5 and $\mathrm{WP}^{8}$ ) liquid media. To prove the transformation, the mannopine and agropine were detected in the hairy roots by paper electrophoresis according to Tanaka's method ${ }^{9)}$ (the improved Petit's method). Hairy root cultures were maintained on a rotary shaker at $85 \mathrm{rpm}$ at $25^{\circ} \mathrm{C}$ in the light (1,500 lux) or dark.

\section{Extraction and isolation of tropane alkaloids}

Dried hairy roots (115 g) of $H$. niger, which had been cultured in B5 liquid medium (200 ml/500 $\mathrm{m} l$ flask, 40 flasks), were extracted with hot methanol. The methanol extract (50 g) was dissolved in $\mathrm{CHCl}_{3}$ and extracted with $0.25 \mathrm{M}$ sulfuric acid. The aqueous fraction was adjusted to $\mathrm{pH} 10$ with $28 \%$ aqueous ammonia and extracted with $\mathrm{CHCl}_{3}$. The $\mathrm{CHCl}_{3}$ layer was evaporated to give a crude alkaloid fraction $(2.93 \mathrm{~g})$. The crude alkaloid fraction was chromatographed on a silica gel column using $\mathrm{CHCl}_{3}$-acetone-MeOH-28\% $\mathrm{NH}_{4} \mathrm{OH}(75: 10: 4.5: 1,75: 10: 7: 1,75: 10: 10: 2$ and $75: 10$ : $16: 2$, successively) to give fractions $1-12$. Some of fractions were further purified on preparative ion pair HPLC with the solvent system, composed of 48 volumes of methanol and 52 volumes of $10 \mathrm{mM}$ sodium 1-heptanesulfonate in $\mathrm{H}_{2} \mathrm{O}$ ( $\mathrm{pH} 4.8$ adjusted with acetic acid) (IPC solvent) to give hyoscyamine (1) (1139 mg), scopolamine (2) $(42.9 \mathrm{mg}), 7 \beta$-hydroxyhyoscyamine (3) (12 mg) and $6 \beta$ hydroxyhyoscyamine (4) (94 mg).

Hyoscyamine $(\mathbf{1})$ Colorless amorphous solid, $[\alpha]_{\mathrm{D}}-15.4(c=1.0, \mathrm{MeOH})$. FAB-MS ; $m / z 290$ 
$[\mathrm{M}+\mathrm{H}]^{+}, \mathrm{C}_{17} \mathrm{H}_{24} \mathrm{NO}_{3}$.

Scopolamine $(2)$ Colorless viscous oil, $[\alpha]_{\mathrm{D}}-15.5(c=0.93, \mathrm{MeOH}) . \mathrm{FAB}-\mathrm{MS} ; m / z 304$ $[\mathrm{M}+\mathrm{H}]^{+}, \mathrm{C}_{17} \mathrm{H}_{22} \mathrm{NO}_{4}$.

$7 \beta$-Hydroxyhyoscyamine (3) Colorless viscous oil. $[\alpha]_{\mathrm{D}}+0.36(c=0.48, \mathrm{MeOH})$. FAB-MS ; $m / z 306[\mathrm{M}+\mathrm{H}]^{+}, \mathrm{C}_{17} \mathrm{H}_{24} \mathrm{NO}_{4}$.

$6 \beta$-hydroxyhyoscyamine (4) Colorless viscous oil. $[\alpha]_{\mathrm{D}}-11.7(c=1.0, \mathrm{MeOH})$. FAB-MS ; $m / z 306[\mathrm{M}+\mathrm{H}]^{+}, \mathrm{C}_{17} \mathrm{H}_{24} \mathrm{NO}_{4}$.

\section{HPLC analysis}

Twenty $\mathrm{mg}$ of the lyophilized hairy roots were extracted with $15 \mathrm{~m} l$ of methanol under reflux for $2 \mathrm{hr}$. The extract was evaporated under reduced pressure to dryness and dissolved in $300 \mu \mathrm{l}$ of $\mathrm{MeOH}$. After filtration, $3 \mu l$ of the solution was injected onto HPLC using YMC packed column $\mathrm{R}$ -ODS-7 and IPC solvent system as an eluent, and monitored at $215 \mathrm{~nm}$. For quantitative analysis the system was calibrated with the authentic sample, purchased from Sigma Co. Ltd. Each experiment was repeated twice.

\section{Results and Discussion}

Hyoscyamus niger was efficiently transformed by direct inoculation of $A$. rhizogenes (strain 15834) on sterile seedlings. After four timed subcultures on hormone-free $1 / 2 \mathrm{MS}$ agar medium containing antibiotics (carbenicillin and vancomycin) to remove the bacteria, the axenic hairy roots were maintained on the B5 agar medium without antibiotics. Transformation of $H$. niger was confirmed by the detection of mannopine and agropine by Tanaka's method ${ }^{9}$.

The hairy roots were cultured in large scale in B5 liquid medium for four weeks and harvested. The methanol extract of the hairy roots was purified by silica gel column chromatograph and preparative HPLC to give four tropane alkaloids. Their structures were elucidate to be hyoscyamine (1), scopolamine (2), $7 \beta$-hydroxyhyoscyamine (3) and $6 \beta$-hydroxyhyoscyamine (4), respectively, from the ${ }^{1} \mathrm{H}-\mathrm{NMR},{ }^{13} \mathrm{C}-\mathrm{NMR}$ and other spectral data. Optical rotation $\left([\alpha]_{\mathrm{D}}-15.4^{\circ}\right)$ of $\mathbf{1}$ showed that optical purity of $\mathbf{1}$ was relatively high. The isolation yield (dry weight) of $\mathbf{1}$ was up to $0.99 \%$, and the yield of $\mathbf{2 , 3}$ and $\mathbf{4}$ were $0.037 \%, 0.010 \%$ and $0.082 \%$, respectively. The yield of $\mathbf{1}$ $(0.99 \%)$ is higher than content of hyoscyamine in mother plants $(0.06 \%$, analyzed from the aerial parts of the mother plants). Therefore the contents of hyoscyamine in the hairy roots should be more than $0.99 \%$ and must be enhanced by the improved culture condition.

The time courses of the growth of the hairy roots and hyoscyamine content of hairy roots cultured in the three kinds of basal media, MS, B5 and WP liquid media, were examined (Fig. 1). In all cases, a single root tip ( $1 \mathrm{~cm}$ long) was inoculated in one flask containing $40 \mathrm{~m} l$ of the three kinds of medium and cultured. Hyoscyamine contents of the hairy roots cultured in MS and B5 media were affected by light, but the growth of the hairy roots were hardly affected by light. In WP medium, both hyoscyamine content and the hairy root growth were hardly affected by light, and the growth of the hairy roots reached up to $498 \mathrm{mg} /$ flask (dry weight) in the dark after 5 weeks of culture. In MS liquid medium, the relatively high growth rate of the hairy roots was obtained in both light and dark, while in B5 medium the growth rate was low in both of light and dark. The dry weight of the hairy roots proliferated 3532 fold in MS medium, 2760 fold in B5 medium and 3750 fold in WP medium. In MS medium, a higher content of hyoscyamine was obtained in the dark $(2.7 \%$ of dry weight at week 4$)$ than in the light (2.3\% at week 5). In contrast, in B5 medium, higher content was obtained in the light $(1.94 \%$ at week 4$)$ than in the dark (1.52\% at week 3$)$. In WP medium, in which the growth of the hairy roots was the fastest, the lowest contents were obtained 


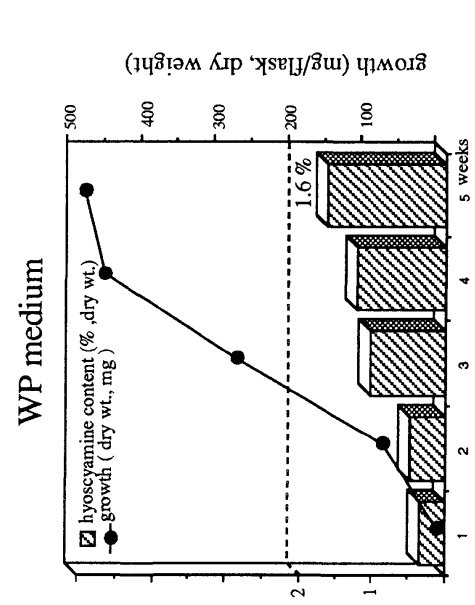

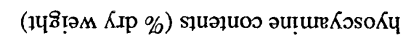

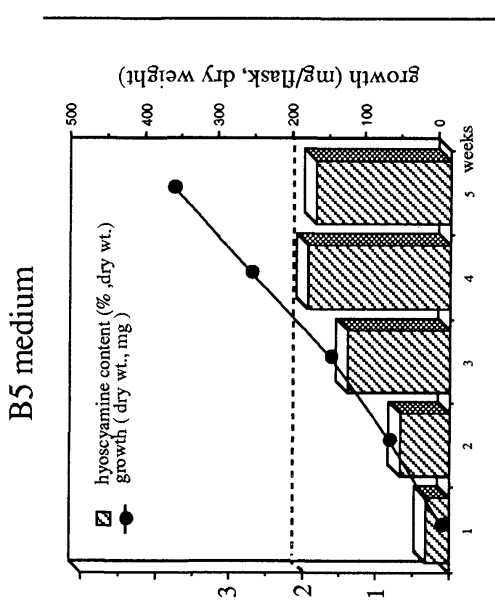

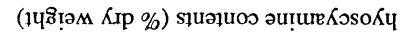

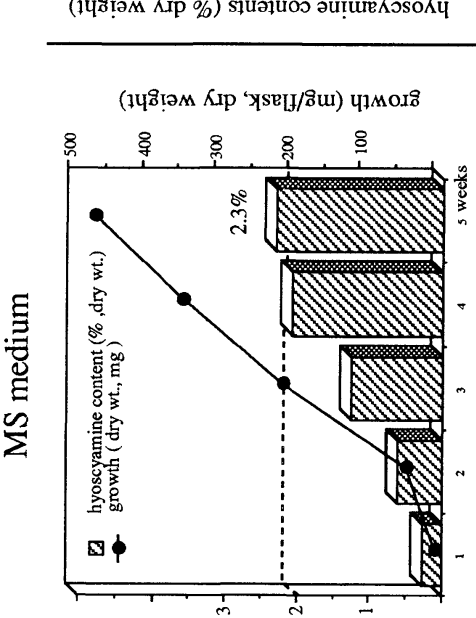

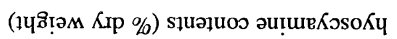

ไบริ!

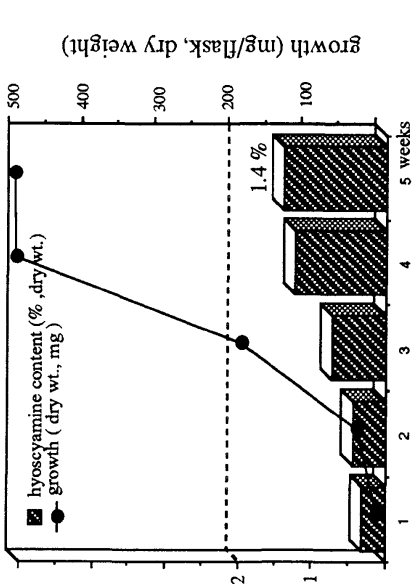

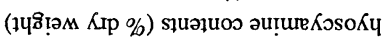

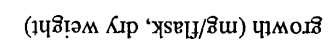

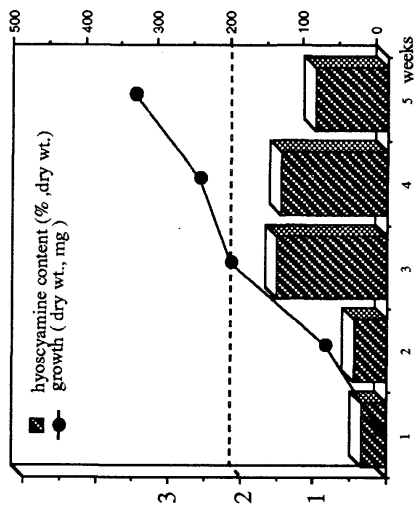

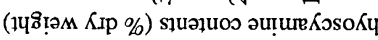

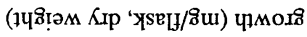

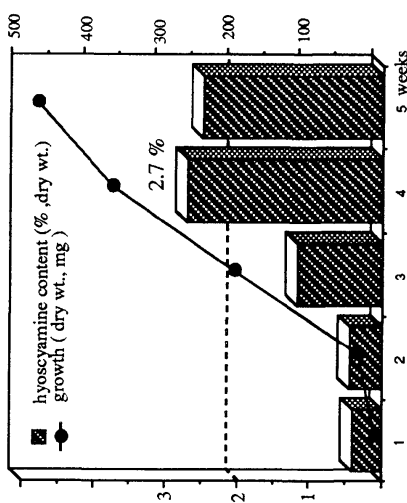

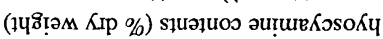

удтр

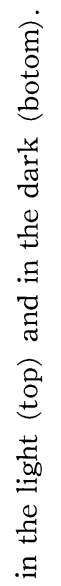

:

:

ב

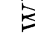

تี

눙

$\sum^{5}$

$\Xi$

$\bar{d}$

$\frac{\mathrm{E}}{3}$

용

高

ฐ

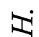

4

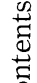

8

.

हี

岁

ב

프

葶

in 

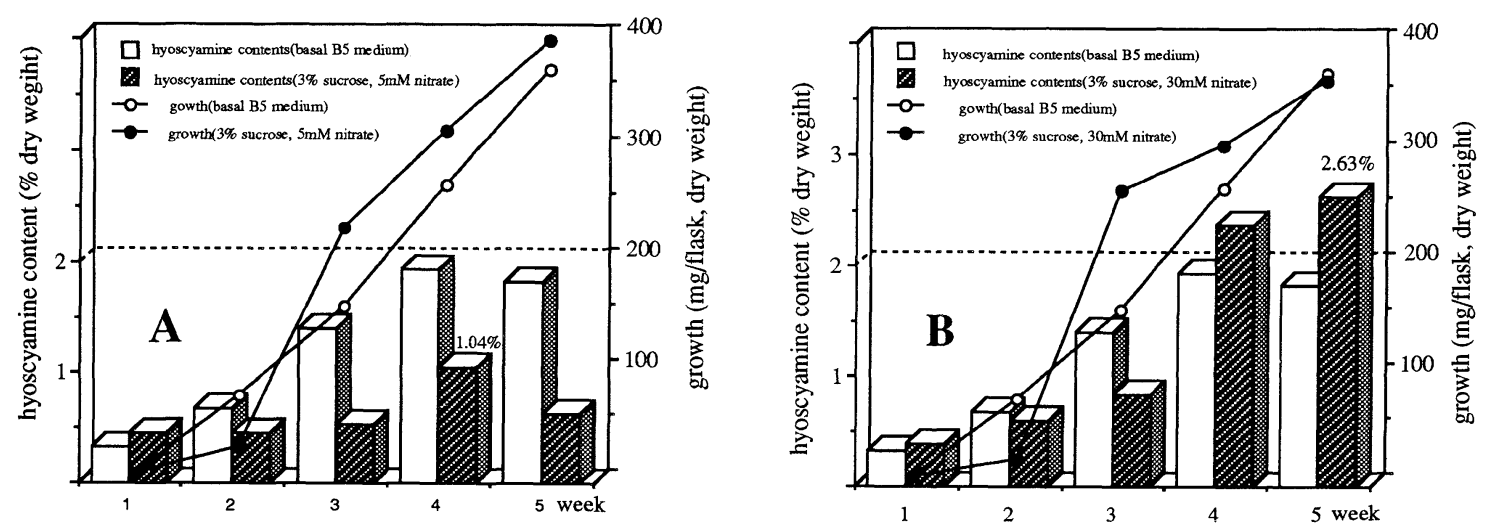

Fig. 2 Growth and hyoscyamine contents of $H$. niger hairy roots cultured in B5 liquid medium with $3 \%$ sucrose and $5 \mathrm{mM}$ nitrate (A) and $30 \mathrm{mM}$ nitrate (B) in the light.

both in the light (1.6\% at week 5$)$ and in the dark (1.4\% at week 5$)$. As mentioned above, the WP medium was most suitable for the growth of hairy roots, and the MS medium was most suitable for hyoscyamine production and the B5 medium was moderate for both of the growth and hyoscyamine production. The morphology of the hairy roots cultured in different media differed from each other. In the MS medium, the hairy roots grew as dark, thick roots. while in the B5 medium the hairy roots grew as white, thin roots. The hairy roots in the WP medium grew like those in B5 medium. We compared the highest hyoscyamine contents in the each medium with the content of hyoscyamine in the aerial part of the mother plants, because aerial parts of $H$. niger are generally used as a tropane alkaloid source. The content of hyoscyamine in the hairy roots cultured in MS, B5 and WP media was 44 fold, 32 fold and 29 fold, respectively, thet of the aerial part of the mother plant.

In a further experiment, we examined the influences of concentrations of sucrose (2-14\%) and potassium nitrate $(0-50 \mathrm{mM})$ on the hyoscyamine content and the growth of hairy roots in the B5 liquid medium, which showed the moderate growth and the relatively high production of hyoscyamine in the light. All increments of sucrose concentration enhanced the growth of the hairy roots, except for $14 \%$. All these conditions caused decrease of hyoscyamine content. The growth of the hairy roots cultured with $3 \%$ sucrose remarkably increased up to $329.9 \mathrm{mg}$ dry weight/flask (188. $5 \mathrm{mg}$ dry weight in B5 medium containing $2 \%$ sucrose). On the other hand, $5 \mathrm{mM}$ and $30 \mathrm{mM}$ concentrations of potassium nitrate gave relatively good growth and high content of hyoscyamine. Therefore we carried out the time course experiment on the growth of the hairy roots and the content of hyoscyamine under different conditions of B5 medium, such as containing $3 \%$ sucrose and $5 \mathrm{mM}$ potassium nitrate, containing $3 \%$ sucrose and $30 \mathrm{mM}$ potassium nitrate and containing $2 \%$ sucrose and $25 \mathrm{mM}$ potassium nitrate (original B5 medium) (Fig. 2). The growth of the hairy roots cultured in different potassium nitrate concentrations showed few differences, but some differences in the hyoscyamine contents (Fig. 2). In the B5 medium containing $3 \%$ sucrose and $30 \mathrm{mM}$ potassium nitrate, the content of hyoscyamine was increased up to $2.63 \%$ dry weight compared with that (1.83\%) in the original $\mathrm{B} 5$ medium ( $2 \%$ sucrose and $25 \mathrm{mM} \mathrm{KNO}_{3}$ ) after 5 weeks of culture.

The hairy roots induced from $H$. niger by the inoculation of $A$. rhizogenes furnished the high growth of more than 3000 fold at week 5 and high production of hyoscyamine (2. 7\%, dry weight), which showed a higher content of hyoscyamine than that by $H$. albus hairy roots ${ }^{10)}$. Hyoscyamine was not detected, in the culture media. 


\title{
Acknowledgment
}

We wish to thank Dr. K. Shimomura of the National Institute of Hygienic Sciences, Tsukuba Medicinal Plant Research Station, for valuable suggestions concerning hairy roots culture. We also thank Dr. M. Uchida of the Analytical Center of University of Shizuoka, for measuring FAB-MS.

\section{References}

1) Ishimaru,K., K. Shimomura, 1989. Phytochemistry, $28: 3507$.

2) Hashimoto, T., Y. Yamada, 1983. Planta Medica, $47: 195$.

3) Flores, H., P. Filner, 1985. In "Primary and Secondary Metabolism of Plant Cell Cultures I", p. 174-185, Springer-Verlag.

4) Shimomura, K., M. Sauerwein, K. Ishimaru, 1991. Phytochemistry, $30: 2275$.

5) Sauerwein, M., K., Shimomura, 1991. Phytochemistry, $30: 3277$.

6) Zambryski, P., J. Temṕe, J. Schell, 1989. Cell, $\mathbf{5 6}: \mathbf{1 9 3 ,}$

7) Yamada, S., N. Noda, J. Hayakawa, K. Uno, 1984. Yakugaku Zasshi, 104 : 199.

8) Lloyd, G. B., B. H. McCown, 1980. Int. Plant Prop. Soc., 30 : 421.

9) Tanaka, N., 1990. Plant Tissue Culture Letters, $7: 45$.

10) Christen, P., T. Aoki, K. Shimomura, 1992. Plant Cell Reports, $11: 597$.

\section{《和文要約》}

\author{
A. rhizogenes の感染によって誘導したヒヨス (Hyoscyamus niger) \\ 毛状根によるトロパンアルカロイドの生産 \\ 内田幸作・黒柳正典・上野 明
}

\section{静岡県立大学薬学部}

Agrobacterium rhizogenes の感染によって誘導したヒヨスの毛状根から主成分として hyoscyamine を高 収率で（分離収率が $0.99 \%$ ）分離し, scopolamine, $6 \beta$-hydroxyhyoscyamine. $7 \beta$-hydroxyhyoscyamineも同時に得た. 分離収率から考えるとhyoscyamine の毛状根による生産量はかなり高く, 培地の 検討の結果 MS 培地では hyoscyamine 含量が高く, WP 培地では増殖が最も良いことが判った. B5 培地 では増殖, hyoscyamine含量ともに余り良くなかったが, 蔗糖, $\mathrm{KNO}_{3}$ の量などを検討することにより hyoscyamine 含量を大幅に向上させることが出来た，なお，MS 培地を用いることで，最も高い hyoscyamine 含量 $2.7 \%$ (乾燥重量) を達成した. 